\title{
Android Based Animals And Plants Name Dictionary Application With Sequential Searching Method
}

\author{
Mugi Raharjo', Musriatun Napiah² \\ ${ }^{1}$ STMIK Nusa Mandiri, ${ }^{2}$ Universitas Bina Sarana Informatika \\ e-mail: ${ }^{1}$ mugi.mou@nusamandiri.ac.id \\ email: ${ }^{2}$ musriatun.mph@bsi.ac.id

\begin{tabular}{ccc}
\hline Diterima & Direvisi & Disetujui \\
$05-04-2021$ & $06-04-2021$ & $12-04-2021$ \\
\hline
\end{tabular}

\begin{abstract}
Abstrak - Smartphone telah menjadi bagian dari kehidupan sehari-hari masyarakat Indonesia, berbagai jenis aplikasi sekarang sudah menjadi kebutuhan untuk membantu pekerjaan manusia dari segi bersosial,teknologi,hiburan bahkan keilmuan. Dalam hal ini penulis membuat aplikasi Kamus Nama Ilmiah atau bahasa latin dari hewan dan tumbuhan berbasis aplikasi android yang merupakan suatu ide atau gagasan dalam pengembangan aplikasi mobile yang memungkinkan penggunanya dapat dengan mudah mencari dan mempelajari kata demi kata dengan mudah dan cepat. Aplikasi ini memungkinkan pengguna dengan cepat mencari arti dari bahasa latin hewan maupun tumbuhan. Proses yang terjadi pada aplikasi ini meliputi pencarian kesamaan kata dengan menggunakan metode pencarian Sequential Searching. Input-an berupa nama hewan atau tumbuhan merupakan nilai string yang akan dijadikan parameter pencarian didalam database. Hasil pengujian Kamus pencarian menggunakan metode Sequential Searching berhasil dengan kecepatan kurang dari satu detik waktu pencarian. Dalam pengujian ini, digunakan kata terdepan dalam database sehingga pencarian kata lebih cepat. Kecepatan proses pencarian menggunakan metode Sequential Searching bergantung kata yang dicari dalam indeks pencarian.

Kata Kunci: Android, Kamus, Bahasa Latin, Sequntial Searching

Abstract - Smartphones have become part of the daily life of Indonesian people, various types of applications have now become a necessity to help human work in terms of social, technological, entertainment and even scientific aspects. In this case, the author makes the Scientific Name Dictionary application or Latin language of animals and plants based on the android application which is an idea or ideas in developing mobile applications that allow users to easily search and learn word by word easily and quickly. This application allows users to quickly look up the Latin meaning of animals and plants. The process that occurs in this application includes searching for word similarities using the Sequential Searching search method. Input in the form of the name of an animal or plant is a string value that will be used as a search parameter in the database. The results of testing the search dictionary using the Sequential Searching method were successful with a speed of less than one second of search time. In this test, the forefront word is used in the database so that word searches are faster. The speed of the search process using the Sequential Searching method depends on the words that are searched in the search index.
\end{abstract}

Keywords: Android, Dictionary, Latin Language, Sequntial Searching

\section{PENDAHULUAN}

Penggunaan ponsel lebih didominasi oleh ponsel pintar yang dikenal dengan nama smartphone. Seiring berjalan waktu, fungsi dasar dari ponsel biasa telah tergantikan dengan hadirnya smartphone. (Sari, 2014), Android merupakan sebuah sistem operasi untukperangkatmobile berbasis Linux yang mencakup sistem operasi, middleware dan aplikasi. Awalnya GoogleInc. membeli AndroidInc. yang merupakan pendatang baru yang membuat softwareuntuk ponsel/smartphone.Aplikasi yang terdapat pada playstore memungkinkan pengguna untuk menginstall berbagai aplikasi yang dibutuhkan pengguna. Fitur-fitur yang disediakan menampilkan beberapa aplikasi untuk memenuhi kebutuhan dan daya tarik tersendiri bagi para penggunanya. Kamus merupakan sebuah media yang dapat diartikan sebagai buku yang berisikan tentang arti suatu kata dari bahasa atau istilah asing. Misalkan untuk istilah nama ilmiah mahkluk hidup, hal ini sangat jelas bahwa kamus tersebut berisikan tentang arti kata dari istilah nama ilmiah mahkluk hidup. Dan keberadaan kamus sekarang sangatlah diperlukan sebagai media yang dapat menambah pengetahuan dan wawasan. Pada saat ini masih mendominasi penggunaan kamus yang berbentuk buku untuk memperoleh informasi khususnya tentang istilah nama ilmiah.

Hal ini menjadikan masyarakat kurang tertarik ketika mencari istilah tentang nama ilmiah mahkluk hidup, Sehingga memberikan efek 2 malas untuk mencari pengetahuan dan wawasan tentang nama ilmiah. Sekarang ini banyak sekali kamus yang beredar, mulai dari bentuk buku, kamus elektronik, aplikasi kamus berbasis dekstop dan web. 
Hewan dan tumbuhan memiliki nama ilmiah, nama ilmiah ini menggunakan bahasa latin, mengapa harus bahasa latin karena bahasa tersebut sekarang sudah tidak digunakan lagi. Bahasa yang sudah tidak digunakan maka bahasa tersebut tidak mengalami perubahan kata, sehingga para ilmuwan yang ingin meneliti hewan dan tumbuhan menggunakan bahasa latin ini untuk mengidentifikasi atau mengenalinya. Maka dari itu untuk mempermudah pembelajaran dalam mengenal nama ilmiah hewan dan tumbuhan kamus ini dibuat.

(Hizbulah Salim, Fitri, 2017), Kamus adalah sebuah buku yang mengandung referensi memuat gabungan kata atau daftar kata dengan keterangan mengenai pelbagai segi penggunaannya dan maknanya dalam bahasa, yang biasanya disusun menurut abjad. (Tresnawati \& Nugraha, 2015) "Aplikasi adalah penggunaan dalam suatu komputer, instruksi atau pernyataan yang disusun sedemikian rupa sehingga komputer dapat memproses input menjadi output. Media pembelajaran adalah segala sesuatu yang dapat menyampaikan dan menyalurkan pesan dari sumber secara terencana sehingga tercipta lingkungan belajar yang kondusif dimana penerimanya dapat melakukan proses belajar secara efektif dan efisien. (Parno, dharmayanti, 2011) "Kebutuhan masyarakat terhadap layanan teknologi berbasis IT sangat bervariatif, salah satu kebutuhan adalah akan ketersediaaan kamus dengan berbagai kepentingan mulai dari kamu yang bersifat umum hingga kamus istilah-istilah khusus seperti kamus politik, kamus ekonomi, kamus psikologi dan sebagainya. (Wahyuningsih \& Mustika, 2020) Proses pada pencarian ini cukup sederhana yaitu menyesuaikan data secara berurut satu persatu hingga data akhir untuk mendapatkan nilai yang sesuai dalam mencari lokasi yang diinginkan oleh pengguna.

(Yuliawan, 2021)Metode sequntial searchdigunakan dengan membandingkan satu kata dengan kata lainnya dalam basis data kamus, pencarian kata ini dilaksanakan denganproses pencarian dari urutan pertama kata dalam basis data kamus sampai dengan kata urutan terakhir. Jika kata ditemukan maka kata yang dicari ditemukan sedangkan apabila kata tidak ditemukan maka kata tersebut tidak terdapat dalam basis data aplikasi kamus.

\section{METODE PENELITIAN}

Untuk mendapatkan data dan informasi yang diperlukan, penulisan menggunakan metode:

1. Pengamatan Langsung Dalam membuat aplikasi ini, metode penelitian yang dilakukan penulis berupa pengamatan interaksi langsung dengan pengguna baik anakanak, orang tua dan guru.

2. Studi Pustaka Penulis melakukan pengumpulan data dan informasi dengan cara membaca buku-buku sebagai referensi yang dapat dijadikan acuan dalam penulisan ini.
(Wijaya, 2019) Adapun langkah-langkah pada proses algoritma sequential searching adalah sebagai berikut :

a. Pertama melakukan perbandingan satu per satu secara berurutan pada perpaduan data dengan keyword yang dicari hingga data tersebut ditemukan atau tidak ditemukan.

b. Pada dasarnya, pencarian ini hanya melakukan pengulangan data dari 1 hingga jumlah data ke-n.

c. Setiap pengulangan yang terjadi, kemudian dibandingkan data ke-i dengan keyword yang sedang dicari.

d. Jika data sama dengan keyword yang ingin dicari, berarti data telah berhasil ditemukan. Kemudian jika hingga akhir dari pengulangan tidak ada data yang sama dengan keyword yang sedang

(Ramadini, Junaidi \& Wibowo, 2021) Sequential search merupakan teknik pencarian data dimana data yang dicari dari data awal sampai akhir secara berurutan berdasarkan kata kunci yang dicari. Kelebihan dari teknik pencarian ini yaitu jika data atau kata kunci yang dicari berada di awal data pencarian, maka data dapat ditemukan dengan cepat. (Latifah dan Abimanyu, 2016) untuk mencari sebuah elemen data yang dilakukan secara berurutan, dengan cara melakukan perbandingan elemen satu persatusecara berurutan samapai elemen yang dicaari ditemukan. Pada perinsipnya algorithma ini melakukan pengulangan atau proses looping mulai dari awal sampai elemen yang dicari ditemukan.

\section{HASIL DAN PEMBAHASAN}

Sebelum aplikasi Android ini di implementasikan dalam bentuk package.apk, maka perlu dirancang terlebih dahulu. Tahap perancangan bertujuan untuk memenuhi kebutuhan pengguna dan memberikan gambaran yang jelas mengenai aplikasi yang kita buat. Keseluruhan dari perancangan ini akan di implementasikan dalam Gadget berbasis android dengan menggunakan perangkat lunak Android Studio. Untuk mengimplementasikan ke dalam program aplikasi dibutuhkan algoritma, yaitu langkah-langkah instruksi sehingga dicapai hasil yang diingikan. Algoritma sequential merupakan sederetan pernyataan-pernyataan urutan dan pelaksaaan eksekusinya runtut, yang lebih dahulu ditemukan (dibaca) akan dikerjakan (dieksekusi).

1. Software Architecture

Rekayasa perangkat lunak merupakan pembangunan yang menggunakan prinsip dan konsep rekayasa dengan tujuan menghasilkan perangkat lunak yang bernilai ekonomi yang dipercaya dan bekerja secara efisien menggunakan mesin. Perangkat lunak banyak dibuat dan pada akhirnya sering tidak digunakan karena masalah-masalah non teknis. Diagram Use Case Use Case merupakan model diagram UML yang digunakan untuk menggambarkan requirement fungsional yang diharapkan dari sebuah sistem 
diagram Use Case menggunakan khususnya pada "siapa" melakukan "apa" dalam lingkungan perangkat lunak yang akan dibangun. Gambar menerangkan dimana pada menu awal aplikasi pertama kali pengguna akan menemui menu utama yang terdiri dari empat button: hewan, tumbuhan, daftar kamus dan info. Dan didalam menu daftar kamus terdapat 2 button hewan dan tumbuhan Adapun use case diagram dalam aplikasi ini sebagai berikut:

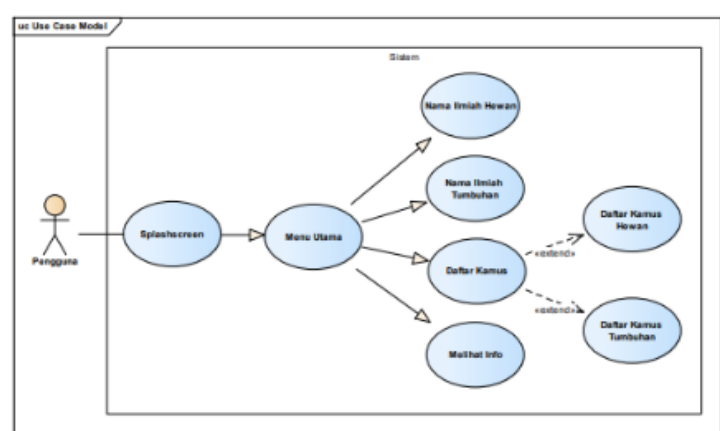

Gambar 1. Diagram use case

\section{Activity Diagram Diagram}

Menggambarkan berbagai aliran aktifitas dalam sistem yang sedang dirancang, bagaimana masingmasing alir berawal, decision yang mungkin terjadi dan akhir dari aktivitas. Activity diagram juga dapat menggambarkan proses paralel yang mungkin terjadi pada beberapa eksekusi. Berikut merupakan beberapa diagram activity dari aplikasi yang dibuat:

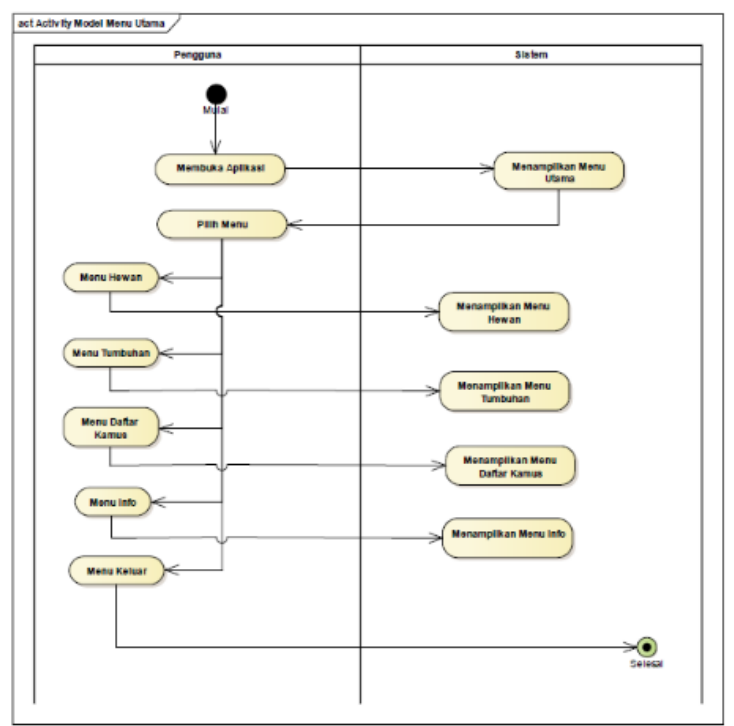

Gambar 2. Activity Diagram Menu Utama

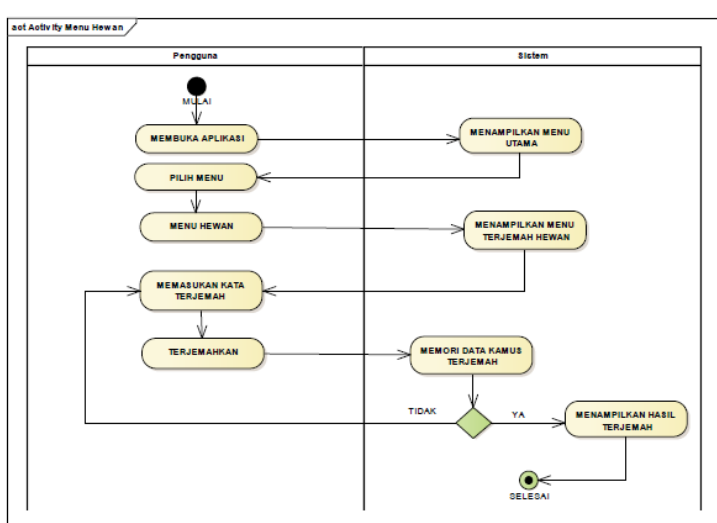

Gambar 3. Activity Diagram Menu Hewan

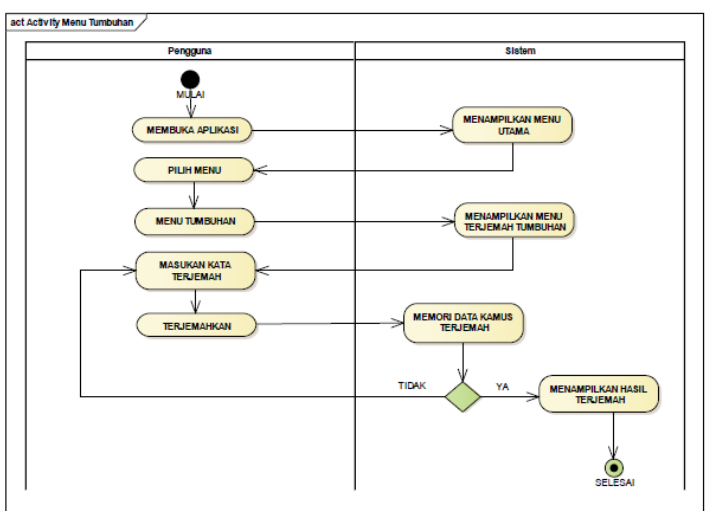

Gambar 4. Acivity Diagram Menu Tumbuhan

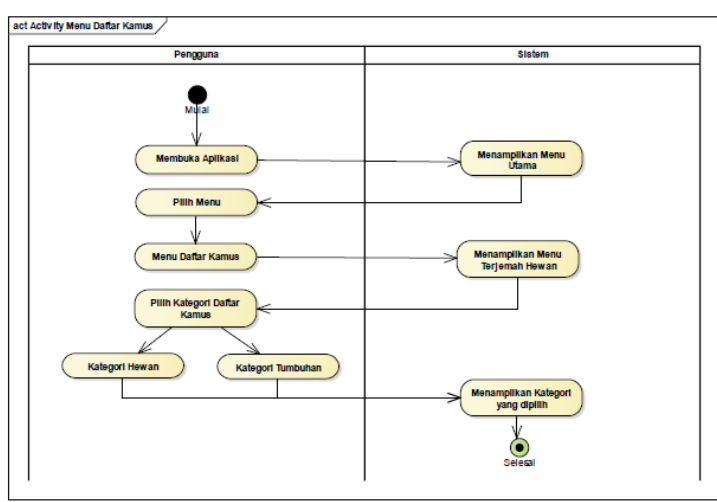

Gambat 5. Activity Diagram Мепи Daftar Kamus

\section{Class Diagram}

Class Diagram merupakan diagram yang memperlihatkan atau menampilkan struktur dari sebuah sistem. Sistem tersebut akan menampilkan kelas, atribut, dan hubungan antar kelas ketika suatu sistem telah selesai membuat diagram. Adapaun class diagram pada aplikasi ini sebagai berikut: 


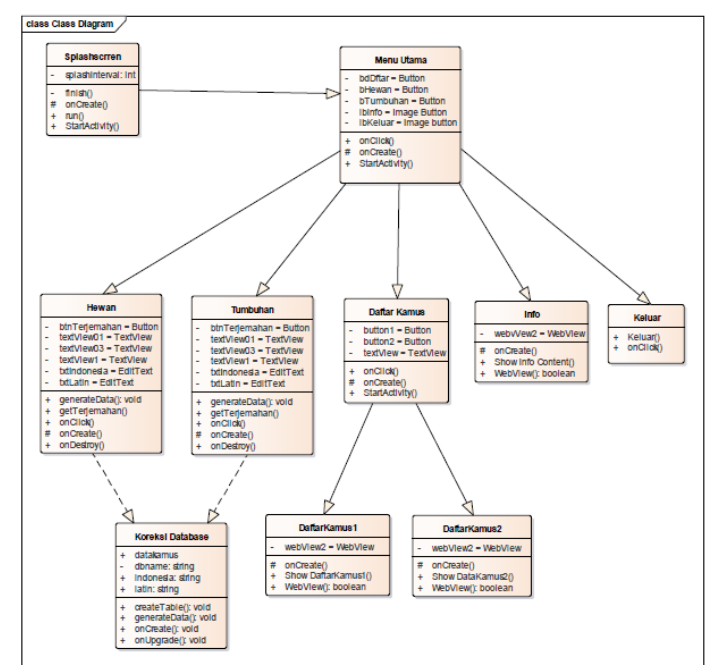

Gambar 7. Class Diagram

\section{Deployment Diagram}

Deployment Diagram merupakan gambaran prosesproses yang berbeda dari suatu sistem berjalan. Diagram ini menjelaskan tentang bagaimana relasi yang tetdapat didalamnya. Adapun Deployment diagram dari aplikasi ini sebagai berikut:

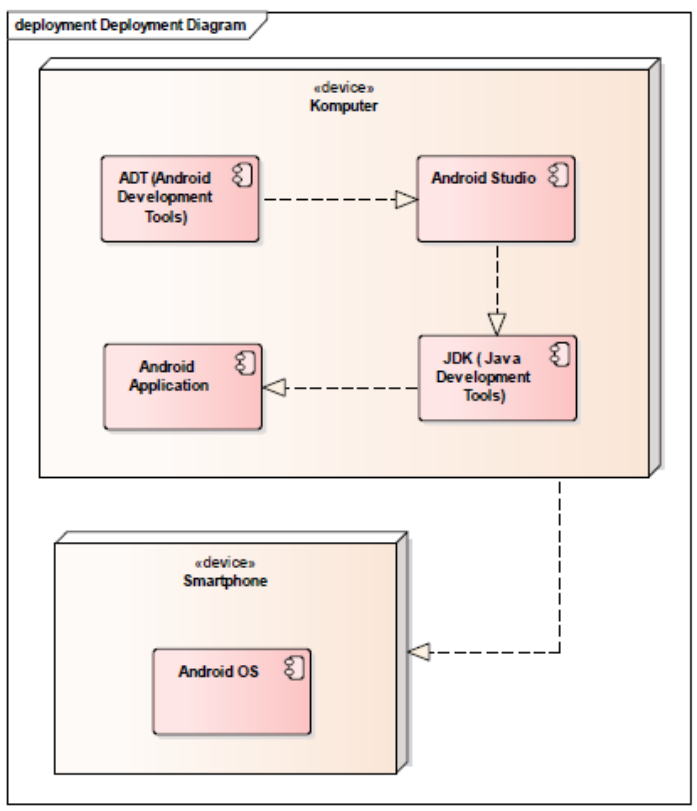

Gambar 8. Deployment Diagram

6. Implementasi

Aplikasi kamus nama ilmiah ini merupakan aplikasi berbasis mobile android. Jadi aplikasi ini dapat dijalankan pada smatphone yang memiliki sistem operasi android. Adapun tampilan yang merancang menggunakan software android studio sebagai berikut:

\section{a. Splash Screen}

Sebelum menampilkan menu utama terlebih dahulu tampil splashscreen yang berguna sebagai feedback bahwa aplikasi tersebut sedang melakukan proses loading.

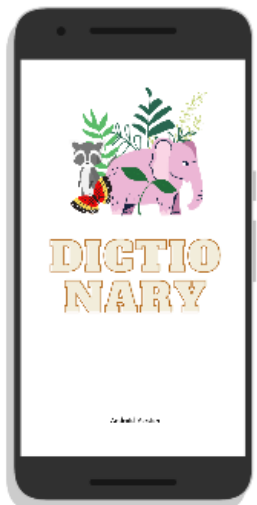

Gambar 9. Tampilan Awal Aplikasi

b. Menu utama

Menu utama berisi buttun-button yang akan mengarah ke halaman selanjutnya. Button-button tersebut adalah hewan, tumbuhan, daftar kamus, info dan keluar.

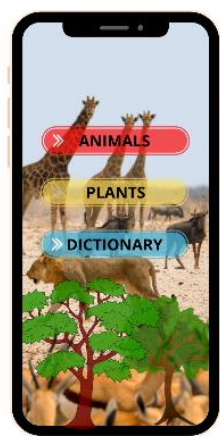

Gambar 10. Tampilan Menu Utama

\section{c. Menu hewan}

Menu hewan ini berisi button,edit text, dan text view dalam menu ini nantinya pengguna akan bisa memasukan kata yang ingin diterjemahkan dalam konteks nama ilmiah. Apabila kata yang dicari tidak terdapat di dalam database maka kolom bahasa latin akan menampilkan "KATA TIDAK DITEMUKAN".

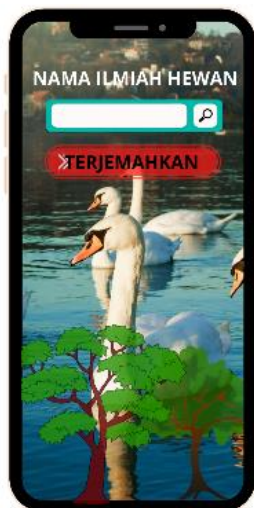

Gambar 11. Tampilan Menu Hewan 


\section{d. Menu Tumbuhan}

Menu tumbuhan ini berisi button, edit text, dan text view dalam menu ini nantinya pengguna akan bisa memasukan kata yang ingin diterjemahkan dalam konteks nama ilmiah. Apabila kata yang dicari tidak terdapat di dalam database maka kolom bahasa latin akan menampilkan "KATA TIDAK DITEMUKAN".

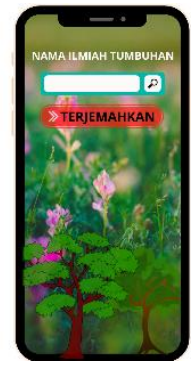

Gambar 12. Tampilan menu Tumbuhan

e. Menu daftar kamus

Menu daftar kamus ini berisi button pilihan yang akan mengarahkan ke halaman selanjutnya, yaitu halaman daftar kamus hewan dan daftar kamus tumbuhan.

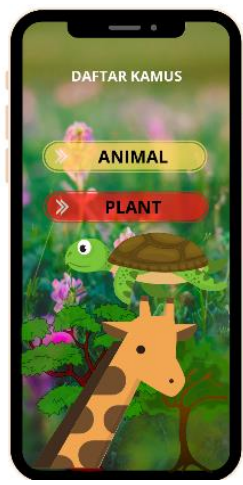

Gambar 13. Tampilan menu pilihan

f. Menu daftar kamus hewan

Menu ini berisi daftar kamus hewan yang diterjemahkan kedalam nama ilmiah atau bahasa latin. Dalam daftar kamus ini disusun sesuai urutan abjad yaitu dari A-Z, jadi pengguna hanya dengan melakukan geser keatas atau kebawah.

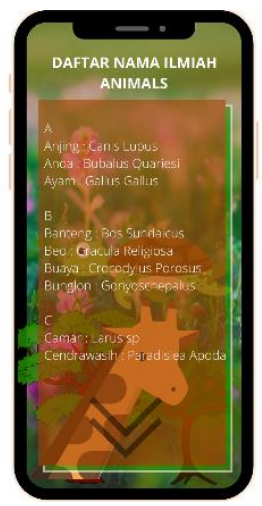

Gambar 14. Tampilan Kamus Hewan g. Menu daftar kamus tumbuhan

Menu ini berisi daftar kamus tumbuhan yang diterjemahkan kedalam nama ilmiah atau bahasa latin. Dalam daftar kamus ini disusun sesuai urutan abjad yaitu dari A-Z, jadi pengguna hanya dengan melakukan geser keatas atau kebawah.

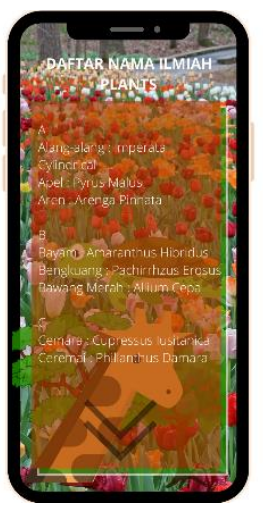

Gambar 15. Tampilan Daftar kamus Tumbuhan

h. Menu info

Menu info ini menampilkan sekilas penjelasan tentang aplikasi dan pembuat aplikasi serta kontak yang bisa dihubungi.

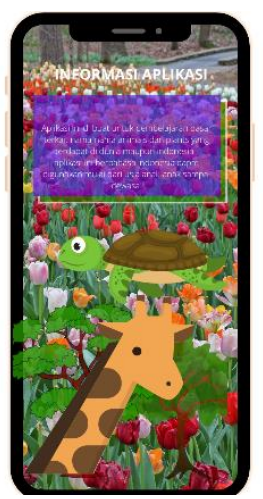

Gambar 16. Tampilan menu info aplikasi

7. Testing

Testing dengan menggunakan white box dan black box untuk pengujian white box. Dengan menggunakan skema diagram alir, berikut merupakan diagram alir dalam aplikasi kamus nama ilmiah tumbuhan dan hewan.

\section{White Box}

Dalam tahap ppengujian white bos ini penulis menggunakan skema diagram alir untuk mendapatkan hasil pengujian yang akurat. Berikut 57 merupakan flowchart dan skema diagram alir aplikasi kamus nama ilmiah tumbuhan dan hewan berbasis android: 


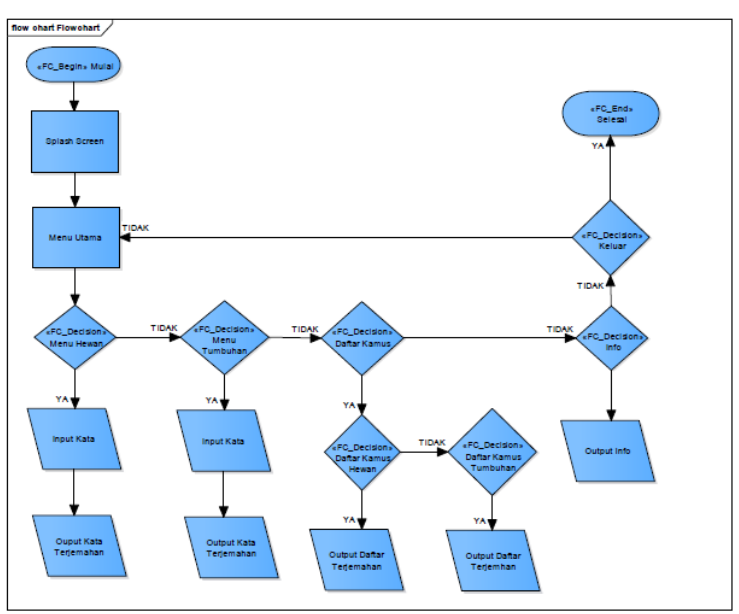

Gambar 17.Flowchart Diagram

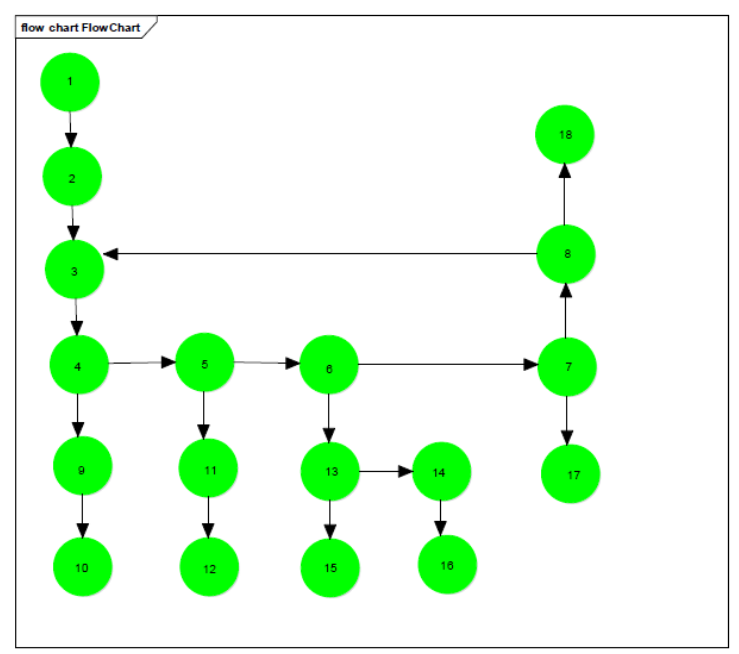

Gambar 18. Diagram air

Dari skema diagram alir diatas dapat diperoleh kompleksitas siklomatis dengan rumus sebagai berikut:

$" V(G)=E-N+2$

$V(G)=$ grafik alur

$E=$ jumlah edge (tanda panah)

$N=$ jumlah node (lingkaran)

$P=$ Predicate nodes (cabang)

$V(G)=22-18+2=6$
a) $1-2-3-4-9-10$
b) $1-2-3-4-5-11-12$
c) $1-2-3-4-5-6-13-15$
d) $1-2-3-4-5-6-13-14-16$
e) $1-2-3-4-5-6-7-17$
f) $1-2-3-4-5-6-7-8-18$

Ketika aplikasi dijalankan ,maka akan terlihat satu set baris yang dihasilkan adalah
1-2-3-4-9-10-3-4-5-11-12-3-4-5-6-13-15-3-4-5-613-14-3-4-5-6-13-14-16-3-4-5-6-7-17-3-4-5-6-7-83-4-5-6-7-8-18

dan terlihat bahwa simpul telah dieksekusi satu kali.

\section{Black Box}

Pengujian selanjutnya dilakukan untuk memastikan suatu masukan menjelaskan proses yang tepat dan menghasilkan output yang sesuai dengan rancangan.

Tabel 1. Pengujian Black box

\begin{tabular}{|c|c|c|c|}
\hline No & Menu & Ujuk Kerja & Keterangan \\
\hline \multirow{2}{*}{1} & \multirow{2}{*}{$\begin{array}{l}\text { Splash } \\
\text { Screen }\end{array}$} & $\begin{array}{l}\text { Menampilkan tampilan splash } \\
\text { creen }\end{array}$ & Berhasil \\
\hline & & $\begin{array}{l}\text { Menampilkan loading saat } \\
\text { splash screen sedang berjalan }\end{array}$ & Berhasil \\
\hline \multirow{7}{*}{2} & \multirow{7}{*}{$\begin{array}{l}\text { Menu } \\
\text { utama }\end{array}$} & Menampilkan tampilan home & Berhasil \\
\hline & & $\begin{array}{l}\text { Menampilkan menu hewan, } \\
\text { tumbuhan, daftar kamus info } \\
\text { dan keluar }\end{array}$ & Berhasil \\
\hline & & $\begin{array}{l}\text { Menampilkan menu hewan } \\
\text { setelah user mengklik menu } \\
\text { hewan dan menampilkan lay- } \\
\text { out berikutnya }\end{array}$ & Berhasil \\
\hline & & $\begin{array}{l}\text { Menampilkan menu } \\
\text { tumbuhan setelah user } \\
\text { mengklik menu tumbuhan }\end{array}$ & Berhasil \\
\hline & & $\begin{array}{l}\text { Menampilkan menu dafta } \\
\text { kamus setelah user mengklik } \\
\text { dan menampilkan }\end{array}$ & Berhasil \\
\hline & & Menampilkan menu info & Berhasil \\
\hline & & $\begin{array}{l}\text { Menampilkan kotak dialog } \\
\text { keluar aplikasi }\end{array}$ & Berhasil \\
\hline \multirow{4}{*}{3} & \multirow{4}{*}{$\begin{array}{c}\text { Menu } \\
\text { Hewan }\end{array}$} & $\begin{array}{l}\text { Memasukkan kata terjemah } \\
\text { dalam kolom edittext }\end{array}$ & Berhasil \\
\hline & & $\begin{array}{l}\text { Menampilkan button } \\
\text { terjemahan }\end{array}$ & Berhasil \\
\hline & & $\begin{array}{l}\text { Menampilkan kata sesudah } \\
\text { user mengklik button } \\
\text { terjemahkan }\end{array}$ & Berhasil \\
\hline & & Menampilan hasil terjemahan & Berhasil \\
\hline \multirow{4}{*}{4} & \multirow{4}{*}{$\begin{array}{c}\text { Menu } \\
\text { Tumbuhan }\end{array}$} & $\begin{array}{l}\text { Memasukkan kata terjemah } \\
\text { dalam kolom editttext }\end{array}$ & Berhasil \\
\hline & & $\begin{array}{l}\text { menampilkan button } \\
\text { terjemahkan }\end{array}$ & Berhasil \\
\hline & & $\begin{array}{l}\text { Menampilkan kata sesudah } \\
\text { user mengklik button } \\
\text { terjemahkan }\end{array}$ & Berhasil \\
\hline & & $\begin{array}{l}\text { Menampilkan hasil } \\
\text { terjemahan }\end{array}$ & Berhasil \\
\hline \multirow{3}{*}{5} & \multirow{3}{*}{$\begin{array}{l}\text { Daftar } \\
\text { Kamus }\end{array}$} & $\begin{array}{l}\text { Menampilkan menu pilih } \\
\text { katagori hewan dan tumbuhan }\end{array}$ & Berhasil \\
\hline & & menampilkan button hewan & Berhasil \\
\hline & & $\begin{array}{l}\text { menampilkan button } \\
\text { tumbuhan }\end{array}$ & Berhasil \\
\hline 6 & $\begin{array}{l}\text { Daftar } \\
\text { kamu } \\
\text { shewan } \\
\end{array}$ & $\begin{array}{l}\text { Menampilkan daftar tentang } \\
\text { terjemahan nama ilmiah } \\
\text { hewan }\end{array}$ & Berhasil \\
\hline 7 & $\begin{array}{c}\text { Daftar } \\
\text { kamus } \\
\text { tumbuhan }\end{array}$ & $\begin{array}{l}\text { Menampilkan daftar tentang } \\
\text { terjemahan nama ilmiah } \\
\text { tumbuhan }\end{array}$ & Berhasil \\
\hline 8 & Menu info & $\begin{array}{l}\text { Menampilkan keterangan info } \\
\text { aplikasi }\end{array}$ & Berhasil \\
\hline 9 & Keluar & $\begin{array}{l}\text { Menampilkan kotak dialog } \\
\text { keluar aplikasi }\end{array}$ & Berhasil \\
\hline
\end{tabular}




\section{KESIMPULAN}

Kesimpulan dalam penulisan ini adalah Aplikasi android memang membantu dalam proses pembelajaran apalagi sekarang jaman digital yang semuanya tidak terlepas dari gadget. Aplikasi kamus memberikan kemudahan dalam mencari suatu kata maupun arti sehingga media pembelajaran melalui aplikasi kamus ini sangat efektif. Selain kamus ada juga buku sebagai media pembelajaran, mengingat kebutuhan masyarakat akan mobilitas tinggi, sehingga aplikasi kamus berbasis android sangat membantu karena tidak perlu repot lagi membawa buku yang mungkin tebalnya melebihi dari kamus bahasa. Kamus ini bertujuan untuk memberikan pembelajaran kepada masyrakat umum yang membutuhkan atau hanya sekedar ingin tahu tentang nama ilmiah dari hewan dan tumbuhan

\section{REFERENSI}

10443.pdf. (n.d.).

Aplikasi, P., Online, K., Metode, M., \& Search, S. (2021). Jurnal dinda, 1(1).

Hizbulah Salim, Fitri, I. (2017). Searching (sequential \& binary search). Jurnal Informatika Merdeka Pasuruan, 3(1), 62-70.

Latifah dan Abimanyu. (2016). Perancangan aplikasi android rekapitulasi hasil pemilu sementara menggunakan algorithma sequential sercing berbasis mobile. Pengertian Konsep Dasar Program, XIII(1), 32-41. Retrieved from http://ejournal.nusamandiri.ac.id/ejurnal/index. php/techno/article/view/263/223

Parno, dharmayanti, N. (2011). Aplikasi Mobile Kamus Istilah_Ug.Pdf. Retrieved from http://repository.gunadarma.ac.id

Sari, I. N. (2014). Aplikasi Kamus Indonesia-Jawa Berbasis Android. Penulisan Ilmiah Universitas Gunadarma, 2(1), 1-5.

Studi, P., Pendidikan, M., Iai, I., Kalijogo, S., \& Pasuruan, D. I. K. (2019). Jurnal Akademika Jurnal Akademika, 1(3), 17-34.

Tresnawati, D., \& Nugraha, T. S. (2015). Pengembangan Aplikasi Pengenalan Kesenian Daerah. Jurnal Algoritma, 12(1), 1-10.

Wahyuningsih, P., \& Mustika, N. (2020). Sistem Informasi Lokasi Sejarah Pahlawan Sulawesi Selatan Menggunakan Algoritma Sequential Search Berbasis Android. Electro Luceat, 6(2), 266-273.

https://doi.org/10.32531/jelekn.v6i2.262 